\title{
Postoperative determination of the degree of carotid artery stenosis
}

\section{Determinação pós-operatória do grau de estenose na artéria carótida}

J. Janzen', P. Chenais', W. Janzen'1, F. Schibler², J. Schmidli

\begin{abstract}
This article describes the VascMorph 1a prototype software and reports first results obtained with postoperative determination of the degree of stenosis in the carotid artery.
\end{abstract}

Keywords: degree of stenosis; atherosclerosis; carotid artery.

\section{Resumo}

Este artigo descreve o programa protótipo VascMorph 1a e apresenta os primeiros resultados obtidos com a determinação pós-operatória do grau de estenose na artéria carótida.

Palavras-chave: grau de estenose; aterosclerose; artéria carótida.

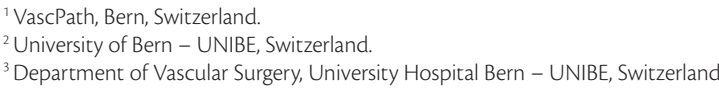




\section{INTRODUCTION}

Vascular surgeons and angiologists have often posed the question about the degree of stenosis of operated vascular specimens. With this goal in mind, the VascMorph 1a prototype software has been developed. The software performs a planimetric procedure which allows to determine the percentage of stenosis. The VascMorph 1a was first tested in atherosclerotic carotid artery samples ${ }^{1}$.

The present paper describes the assessment of a total of 56 endarterectomy samples provided by the Department of Vascular Surgery of the University Hospital of Bern (Head of Department: Prof. Dr. J. Schmidli). Materials obtained from 20 women $(35.7 \%)$ and 36 men $(64.3 \%)$ were examined; mean age was 78.6 years among women and 74.9 years among men.

\section{PREOPERATIVE DETERMINATION OF THE DEGREE OF CAROTID ARTERY STENOSIS}

In order to examine preoperative stenosis, different sonographic and angiographic methods were used (e.g. color-coded duplex sonography, intra-arterial subtraction angiography, magnetic resonance angiography) according to the European Carotid Surgery Trial (ECST) or the North American Symptomatic Carotid Endarterectomy Trial (NASCET). In such diameter-related measurement methods, among other things, an idealized circular shape is assumed for both the vessel lumen and the stenosis. The degree of stenosis is not determined using planimetry, but rather based on differences in the respective flow rates (Figure 1) ${ }^{2-4}$. Occasionally,

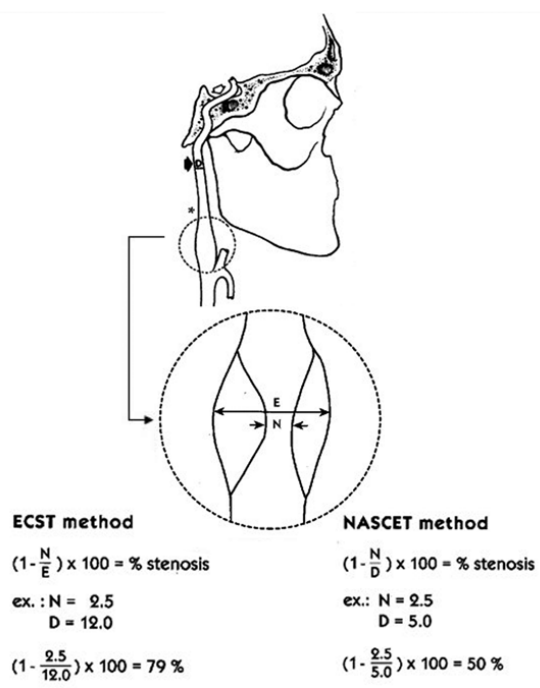

Figure 1. Preoperative stenosis determination based on ECST and NASCET criteria. Both diameter-related calculations are based on differences in the respective flow rates ${ }^{3}$. a correction factor is used to adjust ECST/NASCET values ${ }^{5}$.

\section{POSTOPERATIVE DETERMINATION OF THE DEGREE OF CAROTID ARTERY STENOSIS (VASCMORPH 1A)}

Differently from sonographic methods, in this paper the VascMorph 1a prototype software is proposed. This method represents a planimetric method that can be used postoperatively.

\section{SAMPLE PREPARATION}

Endarterectomy specimens were laminated after conventional formalin fixation and calcification from proximal to distal at a distance of 3-5 $\mathrm{mm}$. Subsequently, sections were embedded in paraffin and stained using the Elastica van Gieson method.

\section{ASSESSMENT OF VASCULAR PATHOLOGY}

Arterial cross sections were assessed following routine microscopic diagnosis (Figure 2), as follows:

- Characterization of plaque configuration and composition (foam cells, cholesterol crystals, hemorrhage, inflammatory infiltrates, connective tissue cap, etc.);

- Definition of the degree of atherosclerosis according to Stary's classification ${ }^{6}$; and

- Determination of the arterial type (elastic muscular, transition zone) $)^{7}$

\section{DETERMINATION OF THE DEGREE OF CAROTID ARTERY STENOSIS}

Carotid artery stenosis was identified and digitally photographed (Figure 2) and uploaded to the VascMorph 1a software (Figure 3). After marking the ideal lumen (Figure 4) and the residual lumen (Figure 5), the degree of stenosis was calculated using the formula below:

Degree of stenosis $(\%)=\frac{\text { Ideal volume }- \text { Residual volume } \times 100 \%}{\text { Ideal volume }}$

\section{COMPARISONOFPRE-AND POSTOPERATIVE MEASUREMENTS}

A total of 56 endarterectomy samples were investigated. Preoperatively, the degree of stenosis was determined using magnetic resonance angiography. In these investigations, the mean degree of stenosis was $65.32 \%$ (standard deviation: 11.939; standard error of the mean: 1.595).

Postoperative determination of the degree of stenosis using VascMorph 1a revealed statistically higher results ( $\mathrm{p}=0.005 ; t$ test), with a mean of $73.95 \%$ (standard deviation: 13.2073; standard error of the mean: 1.7649). 


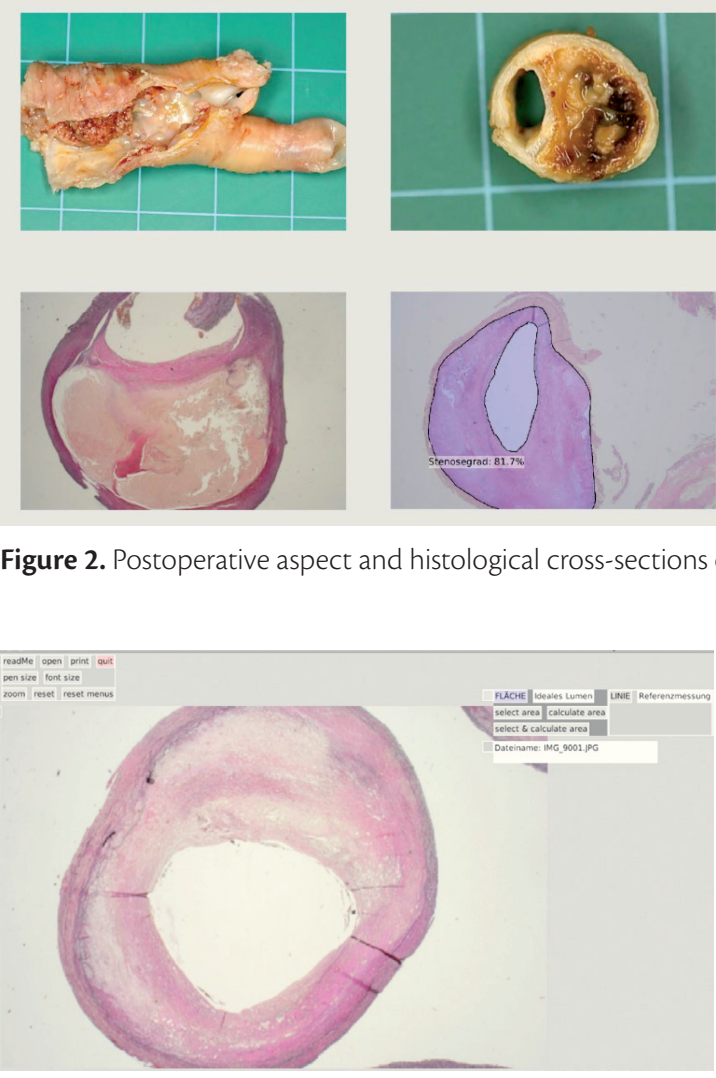

Figure 3. Image of carotid artery stenosis uploaded to VascMorph 1a.

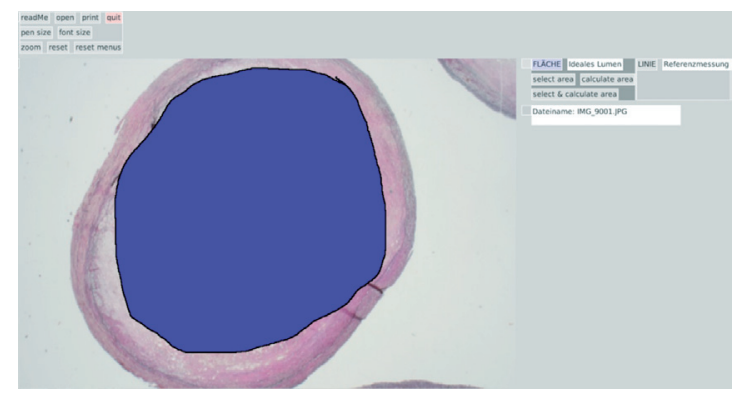

Figure 4. Marking of ideal lumen parallel to internal elastic membrane.

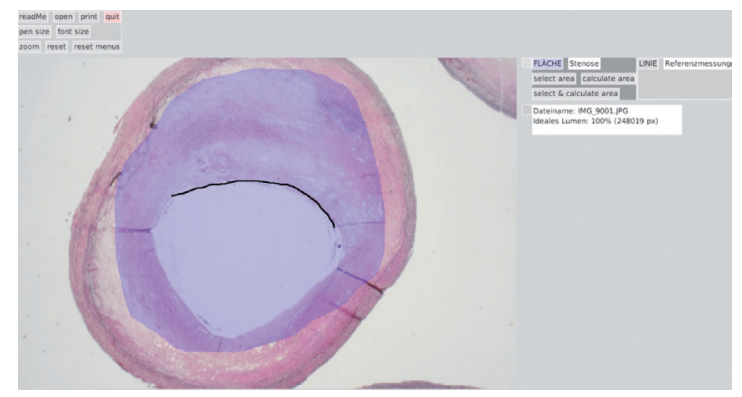

Figure 5. Marking of residual lumen.
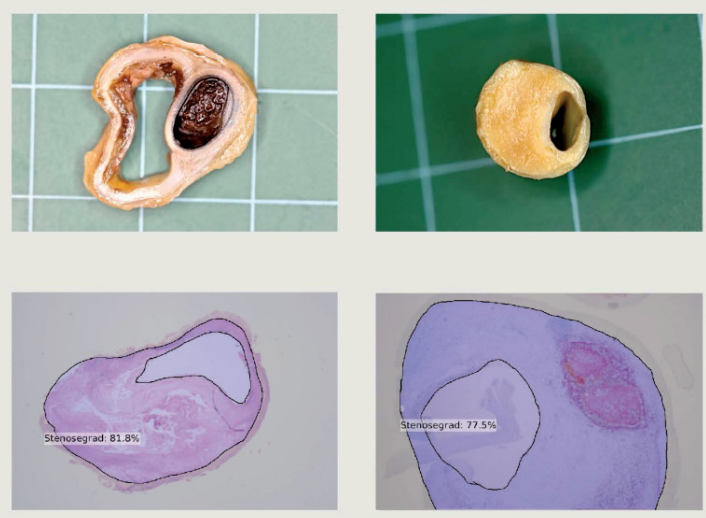

\section{DISCUSSION}

The VascMorph 1a prototype software is a promising tool for microscopic vascular diagnosis. The software not only yields reports on the degree of stenosis of paraffin embedded materials but also allows comparison with values determined preoperatively. The results of our pilot study $(n=56)$ demonstrated a significantly higher degree of stenosis calculated in paraffin-embedded materials when compared to pre-operative values obtained with magnetic resonance angiography, suggesting that calculations made using the planimetric method are more accurate than those made using the diameter-based method, because idealized circularatherosclerotic stenoses are more complex in nature. In the diameter-based method, assumption of the stenosis circular shape causes slit-shaped, elliptical, and scalloped lumina to be ignored. Conversely, in the VascMorph 1a prototype software, different plaque morphologies were easily imaged.

It is worthy to note that about $5-10 \%$ shrinkage may occur as a result of histopathological treatment; this phenomenon equally affects the lumen and thin vascular walls. Conversely, in relatively rigid endarterectomy specimens which hold a high proportion of minerals, no significant shrinkage is expected. In our view, the distortion in measured values is quite low, and does not fall under the current literature classification related to postoperative perfusion of blood vessels ${ }^{8-11}$.

\section{ACKNOWLEDGMENTS}

We are thankful to Dipl.-Math. Brigitta Gahl for helping us with statistics and to Mr. Rafay Siddiqui, MSc, for his assistance in designing the manuscript. 


\section{REFERENCES}

1. Janzen J, Chénais $P$, Schmidli J. Postoperative Stenosegradbestimmung der Arteria carotis (VascMorph 1a), Posterpräsentationen, 99. In: Jahreskongress der Schweizerischen Gesellschaft für Chirurgie; 2012; Davos. Bern: Unionstagung der Schweizerischen Gesellschaften für Gefässkrankkheiten; 2012.

2. Alexandrov AV, Bladin CF, Maggisano R, Norris JW. Measuring carotid stenosis. Time for a reappraisal. Stroke. 1993;24:1292-6. PMid:8362420. http://dx.doi.org/10.1161/01.STR.24.9.1292

3. Veith FJ, editor. Current critical problems in vascular surgery. St. Louis: Quality Medical Publishing; 1994. p. 214. PMid:12320197.

4. European Carotid Surgery Trialists' Collaborative Group. Randomised trial of endarterectomy for recently symptomatic carotid stenosis: final results of the MRC European Carotid Surgery Trial (ECST). Lancet. 1998;351:1379-87. http://dx.doi.org/10.1016/ S0140-6736(97)09292-1

5. Arning C, Widder B, Von Reutern GM, et al. Ultraschallkriterien zur Graduierung von Stenosen der A. carotis interna - Revision der DEGUM-Kriterien und Transfer in NASCET-Stenosierungsgrade. Ultraschall Med. 2010;31:251-7. PMid:20414854. http://dx.doi. org/10.1055/s-0029-1245336

6. Stary HC. Atlas of atherosclerosis: progression and regression. New York: Parthenon; 1999. p. 10-125.

7. Janzen J. Die arterielle Übergangszone. Perfusion. 2004;17 (Suppl 1).
8. Bahr GF, Bloom G, Friberg U. Volume changes of tissues in physiological fluids during fixation in osmium tetroxide or formaldehyde and during subsequent treatment. Exp Cell Res. 1957;12:342-3. http://dx.doi.org/10.1016/0014-4827(57)90148-9

9. Beneš V, Netuka $D$, Mandys V, et al. Comparison between degree of carotid stenosis observed at angiography and in histological examination. Acta Neurochir (Wien). 2004;146:671-7. PMid:15197610. http://dx.doi.org/10.1007/s00701-004-0279-3

10. Bond MG, Insull W, Glagov S, et al. Clinical diagnosis of atherosclerosis. Quantitative methods of evaluation. New York, Heidelberg, Berlin: Springer; 1983. p. 283-303. http://dx.doi. org/10.1007/978-1-4684-6277-7

11. Schwartz JN, Kong Y, Hackel DB, Bartel AG. Comparison of angiographic and postmortem findings in patients with coronary artery disease. Am J Cardiol. 1975;36:174-8. http://dx.doi. org/10.1016/0002-9149(75)90522-6

$\begin{array}{r}\text { Correspondence } \\ \text { J. Janzen }\end{array}$
VascPath Switzerland
PO Box 350
CH-3000 Bern 22 - Switzerland
E-mail: info@janlab.ch

*All authors have read and approved the final version submitted to J Vasc Bras. 